\title{
Sekilas tentang Risiko dan Penyelesaian Hukum terhadap Kredit Macet
}

\author{
Noor Hafidah
}

\begin{abstract}
The Resolution of many unpaid debts needs a legal comprehensif approach. It means that although the basic need is legal aspect, however, it should be based on the legal rule. How the ideal of legal accessories can play in the resolution of unpaid debts, such consistenly implements the rule as in the banking law, not by the other rule nor by illegal ways. The illegal ways can bring to the unjustice of law.
\end{abstract}

\section{Pendahuluan}

Dewasa ini trilyunan rupiah kredit perbankan macet. Dì dalam pola kebijakan ekonomi makro, penyelesaian secara nasional yang diberlakukan terhadap bank adalah dengan memasukkạn ke dalam lembaga Badan Penyehatan Perbankan Nasional (BPPN). Namun, șebenarnya bank sendiri tidak sepenuhnya dapat dipersalahkan. Mobilitas keuangan di bank sebagian besar dipercayakan pada pola aktivitas ekonomi yang bertumpu pada pemberian kredit kepada para nasabahnya yang diharapkan nanti akan kembali lagi.
Dalam pola hubüngan hukum àntara pihak bank dan nasabah terdapat dua pola, yaitu pertama pola hubungan hukum antara bank dengan nasabah penyimpan dana dan kedua pola hubungan hukum antara bank dan nasabah debitur ${ }^{1}$ yang akan dijadikan dasar pijakan dalam membicarakan kredit macet. Hubungan antara bank dan nasabah debitur secara yuridis terikat daiam suatu perjanjian yang secara lazim disebut perjanjian kredit. Akibat hokum dari perjanjian itu melahirkan

'Sutan Remy Sjahdeini. 1993. Kebebasan Berkontrak dan Perlindungan yang Seimbang bagi Para Pihak dalam Perjanjian Kredit Bank di Indonesia. Jakarta: Institut Bankir Indonesia. HIm 122. 
hak dan kewajiban kepada masing-masing pihak. Kepada nasabah debitur mempunyai kewajiban untuk mengembalikan kredit yang telah diperoleh sesuai dengan klausul yang telah disepakati di dalam kontrak sebelum dana dapat dicairkan.

Perjanjian itu tentunya harus memenuhi syarat-syarat perjanjian sebagaimana yang diatur dalam Pasal 1320 KUH Perdata, yakni adanya kesepakatan, adanya kecakapan mereka yang membuat perjanjian, adanya objek tertentu dan karena suatu/sebab yang halal. ${ }^{2}$

Penyelesaian terhadap kenyataan banyaknya kreidt macet memerlukan pendekatan komprehensif dari sisi hukum. Penyelesaian yang dilakukan selama ini lebih ditekankan pada pola-pola ekonomi bahkan politik. Hal itu menimbulkan akibat degradasi terhadap ketentuan hukum di samping menimbulkan diskriminasi. Banyak kredit macet dalam jumlah besar ternyata tidak dapat diselesaikan sesuai dengan ketentuan yang berlaku. Sementara untuk kredit di dalam jumlah yang kecil seringkali diselesaikan secara normatif berdasarkan hukum dengan secara ketat menerapkan klausul-klausul pemberian kredit.

Akibat lebih jauhnya adalah munculnya ketidakadilan yang akan merembes ke berbagai bidang lain seperti ketidakpercayaan kepada dunia perbankan. Adanya semacam mitos bahwa kredit mudah diberikan kepada golongan atau kelompok tertentu, sementara sulit diberikan kepada golongan atau kelompok lain menjadi bukti adanya indikasi itu.

\section{Kredit dan Kredit Macet}

Istilah kredit pada dasarnya adalah penyediaan uang atau tagihan yang dapat dipersamakan dengan itu, berdasarkan persetujuan atau kesepakatan pinjam meminjam. Di dalam kaitan dengan permasalahan ini adalah antara bank dengan pihak lain yang mewajibkan pihak peminjam untuk melunasi utangnya setelah jangka waktu tertentu dengan pemberian bunga (Pasal 1 sub 11 UU No. 10 Tahun 1998 tentang Perbankan).

Klausul dasar dari hubungan kredit perbankan adalah karena adanya kesepakatan antar pihak bank dengan pihak nasabah debitur. Skenarionya sederhana. pihak bank menyediakan uang atau tagihan yang akan digunakan oleh nasabah debitur guna melakukan aktivitas tertentu yang umumnya berorientasi ekonomis. Konkretnya, untuk membiayai aktivitas yang bersifat menguntungkan. Untuk itu pihak bank menerima keuntungan pula dari pinjam meminjam uang tersebut. Sementara itu peminjam juga akan diuntungkan, sebab ia akan memperoleh modal untuk usaha dan dapat melangsungkan usaha tersebut, pádahal sebelumnya tidak memiliki modal yang sangat diperlukan untuk berusaha. ${ }^{3}$

Dari modal yang diperoleh dari pinjaman. bank inilah nasabah debitur akan melakukan kegiatan usahanya dan akan memperoleh keuntungan dari kegiatan usaha tersebut. Jika usahanya terus berputar dengan baik nantinya debitur tersebut dapat mengembalikan kredit beserta kewajiban bunga kepada pihak bank

2Mahmudy Salam. 1990. Perekonomian \& Perbankan. Surakarta: Rahayu Press. HIm. 46.

3/bid: HIm. 56. 
sesuai dengan yang telah diperjanjikan. Dengan demikian, sebenarnya mekanisme hubungan antara pihak bank dengan peminjam adalah suatu hubungan yang saling menguntungkan atas dasar kesetaraan dan kebersamaan.

Berdasarkan hal di atas, pengaturan hubungan hukum antara pihak bank (kreditur) dengan nasabah debitur pada dasarnya adalah persoalan intern mereka bersama yang dari proses awal sampai proses akhir termasuk penentuan syarat-syarat peminjaman, yang kemudian melahirkan hak dan kewajibannya masing-masing adalah hasil kesepakatan.

Prinsip dasar dari kesepakatan sebagaimana dimaksud diatur di dalam Pasal 1338 KUH Perdata yang menyatakan bahwa "semua perjanjian (persetujuan) yang dibuat secara sah berlaku sebagai undang-undang bagi mereka yang membuat". Jadi, para pihak terikat dengan itu serta harus dengan iktikad baik melaksanakan semua klausul yang menjadi kesepakatan bersama.

Sebenarnya inti dari permasalahan kredit itu adalah soal kepercayaan. Kepercayaan dari lembaga bank kepada nasabah (debitur) atau pihak yang meminjam kredit kepada bank tersebut. Kepercayaan menjadi tiitik sentral yang harus dilaksanakan dengan iktikad baik, sehingga masing-masing pihak tidak dirugikan.

Di dalam suatu proses pemberian kredit dari pihak bank kepada nasabah debitur, umumnya melalui beberapa tahapan. Prosedur standar yang biasanya dilalui adalah pertama-tama dengan penilaian terhadap nasabah debitur yang bersangkutan, baik itu menyangkut kelayakan dari usaha yang akan digarapnya, maupun dari aspek personality.
Dari aspek kelayakan usaha, pihak bank akan melihat seberapa jauh faktor kelayakan suatu usaha itu dapat diberikan kredit oleh pihak bank, sehingga peminjaman uang tersebut tidak berisiko tinggi. Berikutnya pihak bank melakukan pengkajian terhadap penilaian yang umumnya dibuat dalam bentuk proposal usaha dan kalau perlu dilakukan observasi. Dari penilaian tersebut juga dipertimbangkan personality aspect (aspek personal) yaitu pihak bank akan melihat aspek kepribadian nasabah debitur untuk memberi tambahan bahan sejauhmana derajat integritas dan kejujuran peminjam ini dapat dipertanggungjawabkan.

Dimaklumi kalau di dalam melakukan penilaian itu pihak bank tidak hanya melihat kepada aturan formal dari birokrasi pemberian kredit, baik yang ditetapkan oleh pihak bank itu sendiri, pihak Bank Indonesia, maupun oleh pihak pemerintah pada umumnya. Ada sisi lain, yaitu naluri kecakapan karyawan bank (bankir) untuk menilai nasabah debitur tersebut. Artinya dalam hal ini faktor pengalaman, pengetahuan, dan kematangan pribadi pada bankir berperan besar di dalam menentukan pemberian kredit. Pada akhirnya, suatu keputusan yang diambil oleh pihak bankir adalah suatu kepercayaan kepada kreditur dengan suatu keyakinan bahwa seorang peminjam memang layak diberikan pinjaman dan akan memenuhi kewajibannya.

Pada tataran aturan formal serta kecerdasan mencermati personality aspect tersebut, maka sebenarnya pemberian kredit adalah kepercayaan yang lazim berlaku di dalam dunia perdagangan baik dalam arti tradisional maupun modern. Di sini yang paling berperan adalah faktor materiil, yakni kematangan seorang bankir dalam menilai 
keadaan peminkam, walaupun misalnya kurang sekali adanya jaminan formal. Bahkan kalau saja banyak diadakan aturan formal dalam pemberian kredit, justru akan menghambat proses pemberian kredit yang oleh seorang bankir berpengalaman tidak dapat daya naluri dagangnya. Artinya semakin banyak diatur hal-hal yang bersifat administratif dan birokratik, maka pada dasarnya hal tersebut menghambat bank dalam berjualan uang (memberikan kredit). Oleh karena itu, masalah naluri dagang pada pemberian kredit ini adalah masalah mendasar, menyangkut kepercayaan seorang bankir terhadap peminjam uang.

\section{Permasalahan Risiko}

Di dalam prinsip usaha, pada dasarnya tidak ada suatu usaha pun yang tidak mengandung risiko. Gambaran konkret dari suatu usaha adalah bahwa setiap usaha yang dilakukan dalam dunia perdagangan sudah disadari bahwa risiko itu akan selalu ada. Begitu pula dalam dunia perbankan, risiko dalam menjalankan usahanya itu juga ada terutama dalam hal pemberian kredit tersebut.

Salah satu risiko bisnis dalam dunia perbankan disstilahkan dengan kredit macet atau kredit bermasalah. kredit bermasalah pada umumnya dikelompokkan ke dalam tiga bagian, yaitu:

1. kredit kurang lancar, yakni apabila terjadi tunggakan bunga yang melampaui tiga bulan, tetapi belum lewat enam bulan, atau kredit telah menunggak pokoknya belum melampaui tiga bulan, tetapi belum lewat enam bulan, atau kredit telah menunggak pokoknya belum melampaui tiga bulan;

2. kredit diragukan, yakni terjadi tunggakan bunga lebih dari enam bulan, tetapi tidak melampaui 27 bulan. Atau pokok kreditnya telah menunggak selama lebih tiga bulan, tetapi tidak melampaui 24 bulan.

3. kredit macet, yakni apabila terjadi tunggakan bunga melebihi dari 27 bulan dan atau telah menunggak kredit pokoknya lebih dari 24 bulan. atau dalam hal ini kredit telah diserahkan kepada saluran hukum yang berlaku seperti Pengadilan, Badan Urusan Piutang dan Lelang Negara. ${ }^{4}$

Disamping itu dalam Surat Keputusan Direksi Bank Indonesia Nomor. 26/22/KEP/DIR tanggal 29 Mei 1993, tentang Kualitas Aktiva Produktif \& Pembentukan Penyisihan Penghapusan Aktiva Produktif jo Surat Edaran Bank Indonesia Nomor. 26/14 BPPP tanggal 26 Mei 1993, kredit dapat digolongkan macet apabila:

1. Tidak memenuhi kriteria lancar, kurang lancar dan diragukan.

2. Memenuhi kriteria diragukan, yaitu :

a. Kredit masih dapat diselamatkan dan agunannya bernilai sekurangkurangnya $75 \%$ dari hutang, termasuk bunga.

b. Kredit tidak dapat diselamatkan tetapi agunannya masih bernilai sekurangkurangnya $100 \%$ dari hutang.

${ }^{4}$ Danang Widiyoko. 1995. Masalah Kredit Macet. Jakarta: Pustaka Antara. Hlm. 56. 
Tetapi dalam jangka waktu 21 bulan sejak digolongkan diragukan belum ada usaha penyelamatan maupun pelunasan.

3. Kredit tersebut penyelesaiannya telah diserahkan kepada Pengadilan Negeri atau Badan Urusan Piutang Negara (BUPN) atau telah diajukan penggantian ganti rugi kepada perusahaan asuransi kredit.

Dengan adanya kredit bermasalah ini memang menjadi beban bagi pihak bank selaku kreditur, apalagi jika kredit bermasalah tersebut telah mencapai jumlah yang besar, yang pada taraf selanjutnya dapat mempengaruhi tingkat likuiditas bank pada umumnya. Ada beberapa kerugian yang dialami oleh bank manakala terjadi kredit bermasalah, yaitu :

1. Bank tidak memperoleh pendapatan dari suku bunga kredit padahal diketahui pendapatan pokok dari bank adalah dari hasil bunga pinjaman kredit ini;

2. Bank harus membentuk biaya cadangan untuk penghapusan pinjaman yang tidak sedikit jumlahnya;

3. Uang yang menjadi kredit macet tersebut, sebenarnya dapat diputar melalui perputaran uang yang akan menghasilkan laba bank lebih besar lagi. Di sini kesempatan memutar uang ini telah tertutup dengan adanya kredit bermasalah tersebut. 5
Dipandang dari sisi peminjam (nasabah debitur), adanya kredit yang tidak dapat dibayar sesuai dengan apa yang diperjanjikan dalam kontrak dengan pihak bank, adalah menjadi suatu beban bagi nasabah debitur yang bersangkutan. Terjadinya kredit bermasalah dapat memproyeksikan tingkat kesehatan usaha yang ia lakukan dalam mengelola keuangan yang telah ia pinjam, dan berdampak tidak baik terhadap nama baiknya (bonafiditas). Pengusaha pada umumnya menjadikan bonafiditas sebagai aset utama dan bonafiditas seorang pengusaha sangat penting artinya untuk mendukung hubungan dengan para relasi yang didasarkan atas asas kepercayaan dan kejujuran.

Timbulnya kredit macet ini, secara positif hakikatnya tidaklah muncul dari suatu niat untuk tidak mengembalikan keuangan yang telah dipinjam dari pihak bank, tetapi memang terjadi dari suatu kondisi pengelolaan uang terhadap usaha yang dilakukan tidak sesuai dengan apa yang telah direncanakan semula. Hal ini dapat terjadi diantaranya karena kesalahan dalam penggunaan uang dan faktor relasi (cash flow) , keadaan ekonomi nasional/global, ataupun keadaan yang tidak dapat dihindari (overmacht). ${ }^{6}$

Di samping itu, secara negatif kredit bermasalah ini dapat terjadi karena adanya niat yang kurang baik dari pihak nasabah debitur, yakni dari semula ia memang sudah berniat untuk tidak membayar kembali

${ }^{5}$ Hairin Umar. 1996. Permasalahan dalam Perbankan. Jakarta: Pustaka Antara. HIm. 67.

'Ibid. Hlm. 58. 
kewajibannya kepada pihak bank tersebut. Kredit bermasalah yang seperti ini biasanya didahului oleh perbuatan yang dalam proses pemberian kredit tersebut tidak sesuai dengan kelayakan pemberian kredit, seperti menggunakan surat-surat sakti, memberikan imbalan yang cukup besar kepada pengelola bank dan kolusi dengan pihak bank. ${ }^{7}$

Hal ini sepertinya sudah merupakan masalah yang jamak di dalam dunia perbankan khususnya pada golongan atas. Buktinya begitu banyak kredit yang macet pada perusahaan-perusahaan milik konglomerat dan perusahaan milik para pejabat pada masa lalu.

Berdasarkan hal tersebut, kredit bermasalah sebenarnya terjadi karena faktor pengelolaan bank, faktor nasabah bank (baik yang positif, maupun negatif) maupun karena terjadinya kolusi antara pihak bank dengan pihak nasabah debitur. Hal ini harus dimengerti sebelum pada akhirnya mencari solusi yang paling tepat guna menyelesaikan berbagai masalah berdasarkan ketentuan yang ada di dalam Hukum Pidana.

\section{Pendekatan Hukum terhadap Kredit Macet}

Permasalahan kredit bermasalah ini pada masa sekarang dirasakan sebagai persoalan yang sangat penting, karena pada sampai akhir bulan maret 1994 sudah terjadi kredit macet yang sangat besar yakni mencapai angka 6,6 trilyun atau sekitar $6,45 \%$ dari total kredit yang disalurkan (belum termasuk kredit yang dikategorikan sebagai kurang lancar dan diragukan. ${ }^{8}$

Untuk mengatasi kredit macet ini sebenarnya sudah ditentukan mekanismenya yang sudah tertuang dalam kontrak kredit antara pihak bank dengan pihak nasabah (peminjam). Artinya kalau memang pinjaman itu tidak dapat dibayar, pada tahap akhir jaminan kreditlah yang akan diambil oleh pihak bank untuk menutupi seluruh pinjaman nasabah. ${ }^{9}$

Akan tetapi biasanya bank mengambil beberapa langkah untuk mengatasi kredit bermasaiah, yaitu dengan cará melakukan pendekatan kepada nasabah debitur untuk bermusyawarah dan sekaligus melakukan penagihan. Manakala penagihan ini tidak dapat juga membuahkan hasil, dalam hal ini bank dapat menempuh cara-cara lain.

Menurut Heru Soepraptomo, seperti dikutip oleh Djuhaendah Hasan mengatakan bahwa apabila upaya preventif telah dilakukan, namun kredit yang diberikan menunjukkan adanya gejala kemacetan, maka bank perlu melakukan upaya refresif dengan cara penjadwalan kembali (rescheduling), persyaratan kembali (recoditioning) dan penataan kembali (restructuring). ${ }^{10}$

Dalam Surat Edaran Bank Indonesia Nomor 26/14/BPP tanggal 26 Mei 1993 juga disebutkan cara-cara penyelamatan kredit bermasalah yaitu:

'Thid.

"Samuel Bangun. "Negara Bangkrut Karena Kredit Macet." Republika. 6 Januari 1999.

${ }^{9}$ Hairin Umar. Op Cit. Hlm. 78.

10/bid. 
1. Penjadwalan kembali (rescheduling) persyaratan kredit yang hanya menyangkut jadwal pembayaran dan atau jangka waktunya.

2. Persyaratan kembali (reconditioning) perubahan sebagian atau seluruh syarat kredit yang terbatas pada perubahan jadwal pembayaran, jangka waktu, dan atau persyaratan lainnya sepanjang tidak menyangkut perubahan maksimum kredit.

3. Penataan kembali (restructuring) perubahan syarat-syarat kredit yang menyangkut:

a. penambahan dana bank atau

b. konversi seluruh atau sebagian tunggakan bunga menjadi pokok kredit baru atau

c. konversi dari seluruh kredit atau sebagian dari kredit menjadi penyertaan dalam perusahaan, yang dapat disertai dengan penjadwalan kembali atau persyaratan kembali.

Tidak tertutup kemungkinan adanya caracara lain yang dapat disepakati oleh kedua belah pihak, seperti berusaha menjual agunan untuk menutupi tunggakan pembayaran. Kalau tidak penyelesaiannya tidak tercapai juga, baru bank biasanya menyerahkan persoalan kredit tersebut kepada lembaga resmi seperti PUPN atau Pengadilan). Hal ini biasanya dinilai sebagai jalan terakhir (ultimum remidium) dan merupakan upaya yang dilakukan setelah semua upaya yang memungkinkan diambil telah dilaksanakan tetapi tidak dapat membuah hasil sebagaimana yang diharapkan. Dengan cara ini padahal akan memunculkan serangkaian masalah baru baik pada nasabah maupun pada Bank pemberi kredit.
Selain itu terdapat sarana hukum yang dapat dipergunakan untuk mempercepat penyelesaian. masalah kredit macet perbankan, yaitu:

1. Peiaksanaan Pasal 1178 ayat (2) KUH Perdata

2. Grosse Akta Pengakuan Hutang dan Hipotik

3. Putusan yang bersifat serta merta (uit voerbaar bij vorraad)

4. Gijzeling dan lijfsdwang.

Disebutkan juga dalam praktek sehari-hari penyelesaian kredit macet dapat dilakukan dengan cara memasukkan piutang kredit tersebut ke dalam perusahaan debitur sebagai saham. Cara-cara sebagaimàna dimaksudkan itu boleh disebut sebagai mekanisme penyelesaian kredit melalui instrumen administratif. Jika kemudian berhasil dalam arti nasabah debitur berhasil mengembalikan uang yang dipinjam berarti cara tersebut menjadi dasar penyelesaian secara ekonomis. Cara-cara itu biasanya diberlakukan terhadap para nasabah debitur kecil. Sedangkan pada nasabah debitur yang besar, yang aktivitas perekonomiannya mempengaruhi roda perekonomian nasional biasanya penyelesaiannya dilakukan dengan pendekatan yang lebih menjurus pada mekanisme politis.

Besar atau kecilnya kredit yang bermasalah seharusnya tetap diselesaikan berdasarkan hukum pidana. Di sini jelas sekali membawa konsekuensi pada dilibatkannya instansi publik (dalam hal ini pengadilan) untuk menyelesaikan kredit macet. Hal ini harus digarisbawahi bahwa sebenarnya tidak ada yang mengharapkan penyelesaian dengan cara ini. baik nasabah maupun Bank sendiri 
tidak menghendaki penyelesaian yang sebenarnya akan membawa kerugian bagi semua pihak. Terlebih lagi bagi kredibilitas dan bonafiditas pengusaha.

Mencermati mekanime dari penyelesaian kredit bermasalah di atas, sebenarnya hanyalah menyangkut persoalan hukum perdata, sebagai suatu hubungan hukum yang bersifat antar personal yaitu Bank dan nasabah. Mekanisme penyelesaiannya pun juga sudah mereka sepakati dalam perjanjian kresit tersebut. namun seperti dikatakan instrumen hukum berkait dengan penyelesaian kredit macet biasanya sudah melibatkan lembaga lain.

Kasus mega kredit BAPINDO dan munculnya pembicaraan Debt Collector adalah contoh yang sudah menjadikan persoalan kredit macet tidak lagi sekedar soal hukum perdata semata-mata. Permasalahannya telah menjadi berkembang sehingga menyangkut instrumentasi dari hukum pidana.

Diselesaikannya persoalan kredit macet melalui jalur hukum pidana itu berkait erat dengan keberadaan kredit perbankan sendiri yang mempunyai dampak yang sangat besar terhadap kondisi moneter dan perekonomian nasional. Oleh karenanya pemerintah telah mengeluarkan berbagai kebijakan dalam kerangka mengendalikan kredit perbankan tersebut. kebijakan ini menyangkut penentuan suku/tingkat bunga, pemberian kredit pada sektor perekonomian yang membutuhkan dukungan dana dan kebijakan yang menyangkut prinsip kehati-hatian dalam pemberian kredit. Hal tersebut dapat dilihat dari:

1. Kebijakan-kebijakan yang seperti tertuang dalam Pakto 1988, mengenai Legal Lending Limit, yang berisi aturan untuk mencegah terkonsentrasinya pemberian kredit kepada golongan tertentu saja ;

2. Kebijakan dalam Pakjan 1990, menyempurnakan sistem perkreditan dengan mengarahkan penyaluran kredit kepada kegiatan-kegiatan yang produktif, usaha kecil dan koperasi, serta menempatkan Bank Indonesia sebagai suatu "lender of the last resort"

3. Kebijakan Fakpeb 1991, mengatur lebih jauh tentang konsentrasi kredit perbankan, yakni maksimum. kredit yang boleh diberikan kepada debitur individu adalah maksimal $29 \%$ dari modal bank dan untuk nasabah kelompok (group) sebesar maksimal $50 \%$ dari modal bank .

4. Undang-Undang No. 7 tahun 1992, mengganti UU No. 14 Tahun 1967, yang dalam pertimbangannya menyatakan bahwa ketentuan undang-undang baru ini dalam kerangka mengacu kepada perkembangan perekonomian nasional dan internasional yang bergerak cepat.

5. Dan terakhir dikeluarkannya UU perbankan yang terbaru yaitu UU No. 10tahun 1998 tentang Perubahan atas UU No. 7 Tahun 1992 tentang perbankan, yang merupakan penyempurnaan dari UU No. 7 Tahun 1992 yang lebih menekankan pada aspek pengembangan dunia perbankan yang semakin kompetitif dan terintegrasi dengan tantangan yang semakin kompleks serta sistem keuangan yang semakin maju.

Dengan melihat posisi kredit bank yang sedemikian penting itulah, maka permasalahan penyelesaian kredit macet dirasakan tidak cukup penyelesaiannya dengan aspek hukum perdata saja. Apalagi mekanisme penyelesaian melalui jalur hukum perdata seperti melewati lembaga peradilan perdata, 
dirasakan berbelit-belit dan memakan waktu yang lama dan memerlukan biaya yang mahal, sehingga pihak bank jarang sekali mengajukan masalah kredit macet ini ke pengadilan.

Hukum pidana, melalui Undang-Undang Nomor 10 Tảhun 1998 tentang Perubahan . atas UU No. 7 Tahun 1992 tentang Perbankan. memberikan sanksi pidana dengan kualifikasi tertentu (pasal $46 \mathrm{~s} / \mathrm{d} 50$ a), baik kejahatan dengan sasaran bank maupun kejahatan yang menggunakan bank sebagai sarananya. perbuatan yang dilarang oleh UU mencakup 3 hal; Pertama, larangan membuka praktik bank gelap atau tanipa ijin pihak berwenang. Ancaman hukumannya adalah penjara maksimal 15 tahun dan atau denda sekurangkurangnya 10 milyar dan maksimal 200 milyar.

Kedua, larangan membuka rahasia bank yaitu membuka rahasia tanpa ada perintah yang diberikan oleh UU. Misalnya dalam tindak pidana khusus seperti korupsi, subversi tindak pidana ekonomi dan lain-lainnya dengan ancaman hukuman maksimal 4 tahun dan denda minimal 10 milyar dan maksimal 20 milyar. Ketiga, larangan yang ditujukan kepada pengurus inti bank (anggota, dewan komisaris, direksi dan pegawai bank) yang melakukan perbuatan bertentangan dengan yang telah digariskan oleh UU dengan berbagai kualifikasi yang sifatnya adalah penyimpangan. Hukuman pidananya maksimal adalah 2 sampai 10 tahun penjara dan atau denda berkisar antara 5 sampai dengan 100 milyar.

Berbagai ancaman itu sampai sekarang belum dapat diterapkan secara konsisten. Ada 2 (dua) hal pokok yang menjadi penyebabnya. Perama kelemahan perangkat hukum, khususnya pada level peraturan perundangan di bawah UU, kedua lemahnya penindakan aparat, khususnya pegawai internal. Pada hal yang pertama, berbagai peraturan perundangundangan seperti Instruksi Presiden, Instruksi Menteri, dan sebagainya menghendaki keselarasan dengan UU sebagai aturan pokok. Kebijakan sektor perbankan belakangan ini mencerminkan inkonsistensi. pada level pengaturan dimaksud. beagai aturan yang dinilai bertentangan dengan jiwa UU Perbankan harus ditinjau kembali.

Pada hal yang kedua, urgensinya kerjasama lebih konkret antara aparat pengawas internal dengan aparat penegak hukum sehingga penegakan hukum itu tidak berjalan sendirisendiri. Adanya perbedaan perspeftik penyelesaian membuktikan hal ini, agar kekusutan dapat berakhir, kuncinya hanya satu, yaitu tegakkan hukm (dengan menjatuhkan sanksi) secara konsisten sesuai dengan UU Perbankan. Tanpa konsistensi ini, perbankan kita akan sulit bangkit dan perekonomian Indonesia akan semakin terpuruk.

\section{Simpulan}

Hukum yang tercermin melalui peratuan perundang-undangan pada dasarnya merupakan instrumen pengakomodasian. Maksudnya keberadaannya adalah sebagai bentuk konkret dari rambu-rambu dalam berbagai bidang lain seperti politik, sosial dan ekonomi. keberadaan peraturan perundangundangan yang mengatur berbagai bidang itu tentunya harus ditaati secara konsisten dan konsekuen.

Macetnya mega-mega kredit dan juga kredit-kredit kecil yang jelas-jelas menyimpang harusnya dicermati berdasarkan perspeftif hukum. harusnya ketentuan yang berhubungan dengan aspek pidana di dalam UU Perbankan yang dengan tegas mematok sanksi 
ditegakkan secara konsekuen. UU itulah yang seharusnya dijadikan parameter di dalam melakukan tindakan terhadap maraknya kredit macet.

Tesisnya sederhana, jika sanksi tersebut tidak ditegakkan secara benar maka kredit macet, kredit bermasalah dan kualifikasi lainnya masih akan terus bertambah. pada. akhirnya negara dan rakyat juga yang dirugikan. Di dalam perspektif hukum keadaan ini menimbulkan ketidakadilan dan ketidakpastian hukum. Adanya peraturan perundang-undangan pada hakekatnya adalah untuk dilaksanakan.

\section{Daftar Pustaka}

Bangưn, Samuel. “Negara Bangkrut Karena Kredit Macet." Republika. 6 Januari 1999.

Salam, Mahmudy. 1990. Perekonomian \& Perbankan. Surakarta: Rahayu Press.

Sjahdeini, Sutan Remy. 1993. Kebebasan Berkontrak dan Perlindungan yang Seimbang bagi Para Pihak dalam Perjanian Kredit Bank di Indonesia. Jakarta: Institut Bankir Indonesia:

Umar, Hairin. 1996. Permasalahan dalam Perbankan. Jakarta: Pustaka Antara.

Widiyoko, Danang. 1995. Masalah Kredit Macet. Jakarta: Pustaka Antara. 